\title{
Watershed Characteristics and Their Implication for Hydrologic Response in the Upper Sokoto Basin, Nigeria
}

\author{
Ifabiyi Ifatokun Paul ${ }^{1} \&$ Eniolorunda Nathaniel Bayode ${ }^{2}$ \\ ${ }^{1}$ Department of Geography and Environmental Management, Faculty of Business and Social Sciences, \\ University of Ilorin, Ilorin, Kwara State, Nigeria \\ ${ }^{2}$ Department of Geography, Usmanu Dan Fodiyio University, Sokoto, Nigeria \\ Correspondence: Ifabiyi Ifatokun Paul, Department of Geography and Environmental Management, Faculty of \\ Business and Social Sciences, University of Ilorin, P.M.B. 1515 Ilorin, Kwara State, Nigeria. E-mail: \\ tokunifabiyi@yahoo.com
}

Received: May 19, 2011 Accepted: June 23, 2011 Online Published: May 28, 2012

doi:10.5539/jgg.v4n2p147 URL: http://dx.doi.org/10.5539/jgg.v4n2p147

\begin{abstract}
Most African river basins lack flow data, a condition which has affected river basin operations. Flood is a common occurrence on the Sokoto basin but poor data base has affected various research efforts and flood mitigation attempts in the basin. This present study will study basin variables using a GIS approach with a few to gaining insights to the flood potentials of Sokoto basin. Shuttle Radar Topographic Mission (SRTM) image covering $5^{\circ}-7^{\circ} \mathrm{E}$ and $12^{\circ}$ to $14^{\circ} \mathrm{N}$ was used in this study. The analysis was carried out using the Integrated Land and Water Information System (ILWIS) and ArcGIS environments. Sinks were removed from the STRM, and the flow direction map was generated as an input for drainage extraction, river ordering and basin catchment extraction. Drainage network overlay was carried out on the generated hill-shade map and on a portion of SPOT image covering the Upper Sokoto catchment for visual analysis. Altogether, 44 basin variables were generated with a view to appraising flood and water resource management in the basin. The results showed that the Upper Sokoto basin is an alluvial catchment; located in a relatively low lying area where high level of deposition is experienced. It is sinuous in nature, circular in shape and compact. These characteristics coupled with the relatively high volume of precipitated water of 14,511,439,620 $\mathrm{m}^{3} /$ year are indications that the basin has high flood potential. The paper recommends construction of levees to protect farmlands, efficient reservoir operation and sustainable watershed management for the purpose of environmental management in the Sokoto basin.
\end{abstract}

Keywords: SRTM, ILWIS, drainage density, sinuosity ratio, compaction ratio, fitness ratio, hydrology

\section{Introduction}

One of the major problems of watershed management in Nigeria is the problem of availability of flow data. Many of the basins are ungagged. Reasons for this include inadequate funding, inadequate manpower, lack of necessary equipment, inaccessibility of some of the gauge stations, lack of political will, among others. This situation is further complicated by the fact that many of these basins are faced with annual hydrologic mishaps such as flood, low flow, erosion, siltation, sedimentation, etc. some of which claim lots of lives and destroyed properties annually. Lack of necessary data has continuously made various government planning efforts to fail, and has sometimes made planning almost impossible. Further, lack of flow data or the use of disjointed data has affected the quality and execution of hydraulic projects in Nigeria. For example, many culverts and bridges have failed; some dams are being overtopped due to inadequate spillway, while others have out- rightly collapsed. All these point to the nature of water resource management problems in Nigeria.

Under the above scenario, water resources research and development efforts in Nigeria will be left with no alternative than to depend to a large extent on analyzing basin variables and the use of simple coefficients in order to provide hydrologic explanations. Analysis of drainage basin characteristics could offer alternative opportunity which some level of planning and project execution could be based.

Drainage basin characteristics are of different types and they are used to measure different hydrological attributes. Prominent amongst them is the drainage density; which has been described as a variable representing 
the interaction between climate and geomorphology (Rodriguez-Iturbe \& Escobar, 1982). It has also been described as a measure of climate, vegetation and topography (Pinchemel, 1957; Melton, 1957; Ruhe, 1958; Slaymaker, 1962; Strahler, 1964; Woo dyer \& Brookfrield, 1966; Morgan, 1976; Gregory, 1976; Yildiz, 2004; Sreenivasulu \& Bhaskar, 2010). Relief ratio, measures basin physiography. It has been found to associate with sediment loss and it is often used for hydrologic modeling (Berger \& Entakhabi, 2001). It has been found to relate to stream gradient, drainage decay, maximum slope, basin shape; etc. Stream frequency is the ratio of total number of stream to basin area. Drainage intensity measures the ability of the basin to discharge its water. This parameter has implication on flood management. Texture topography is the level of topography dissection. Relief gradient is indicative of the differences in elevation. Bifurcation ratio is a measure of how one basin order discharges water into another. This is also relevant in hydrograph time relation (Chorley, 1969); as bifurcation ratio reduces, so also flood incidences increase. The shape of a basin affects the time of peak, time of concentration and peak drainage. Basin sinuosity describes the meandering nature of the basin. Sinuosity has implications on time to peak, sedimentation, erosion, and water quality and aquatic life (Schultz, 1963; Leopold \& Wolman, 1951; Chow, 1964), Width- length- ratio is a measure of the time it takes for water to reach major water courses. High value suggests high runoff duration.

The use of morphometric parameters is imperative in view of the scanty flow data of Nigeria river basins; it remains the major alternative for assessing hydrologic potentials of river basins. This present study will measure basin variables in the Sokoto basin using GIS approach with a view to assessing the flood and water resources potential of this basin.

\section{Study Area}

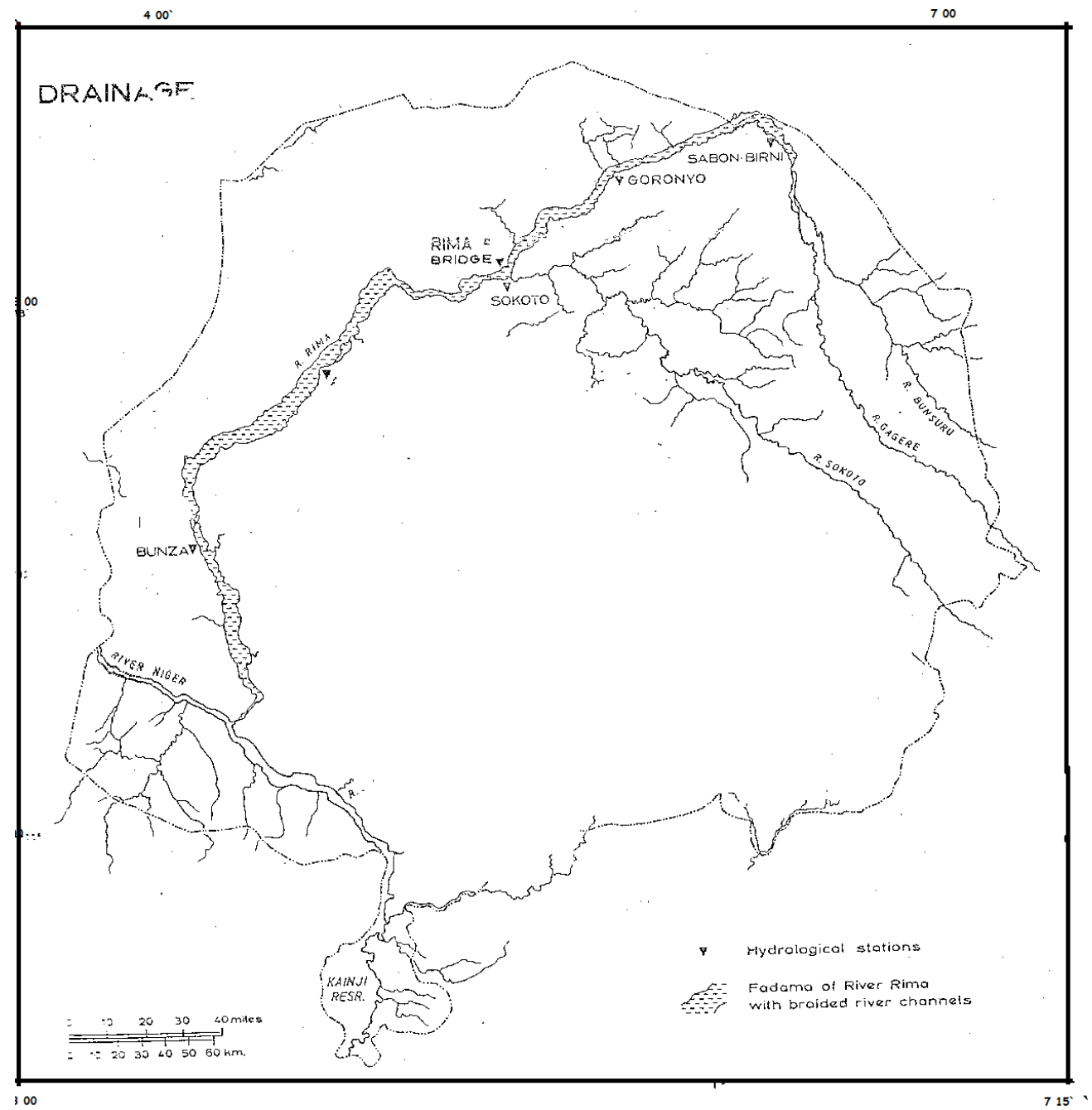

Figure 1. Upper Sokoto Basin 
Rainfall is highly seasonal and controlled by the movement of the Inter Tropical Discontinuity (ITD). Most rainfall is experienced during the relatively short but intense localized thunderstorm covering small areas. Diurnal concentration of rain shows occurrence mainly in the afternoon and early morning. In some years rainfall is evenly dispersed throughout, in some other, it may occur irregularly but in large amount. This will affect runoff characteristics. Rainfall characteristics vary from place to place. Rainfall varies from $658 \mathrm{~mm}$ in Gwadabawa to $1,115 \mathrm{~mm}$ in Faskari. There is a prominent seasonal variation in temperature and diurnal range of temperature. Daily maximum temperature is about $36^{\circ} \mathrm{C}$. During the harmmattan season, daily minimum temperature 1 falls below $17^{\circ} \mathrm{C}$. Between February and April which is the peak of heat, temperature reaches the highest of $44^{\circ} \mathrm{C}$. Range of temperature is generally high. Indeed, Sokoto basin is one of the few areas fingered for having more acute climate change impact in Nigeria (Odjugo, 2010).

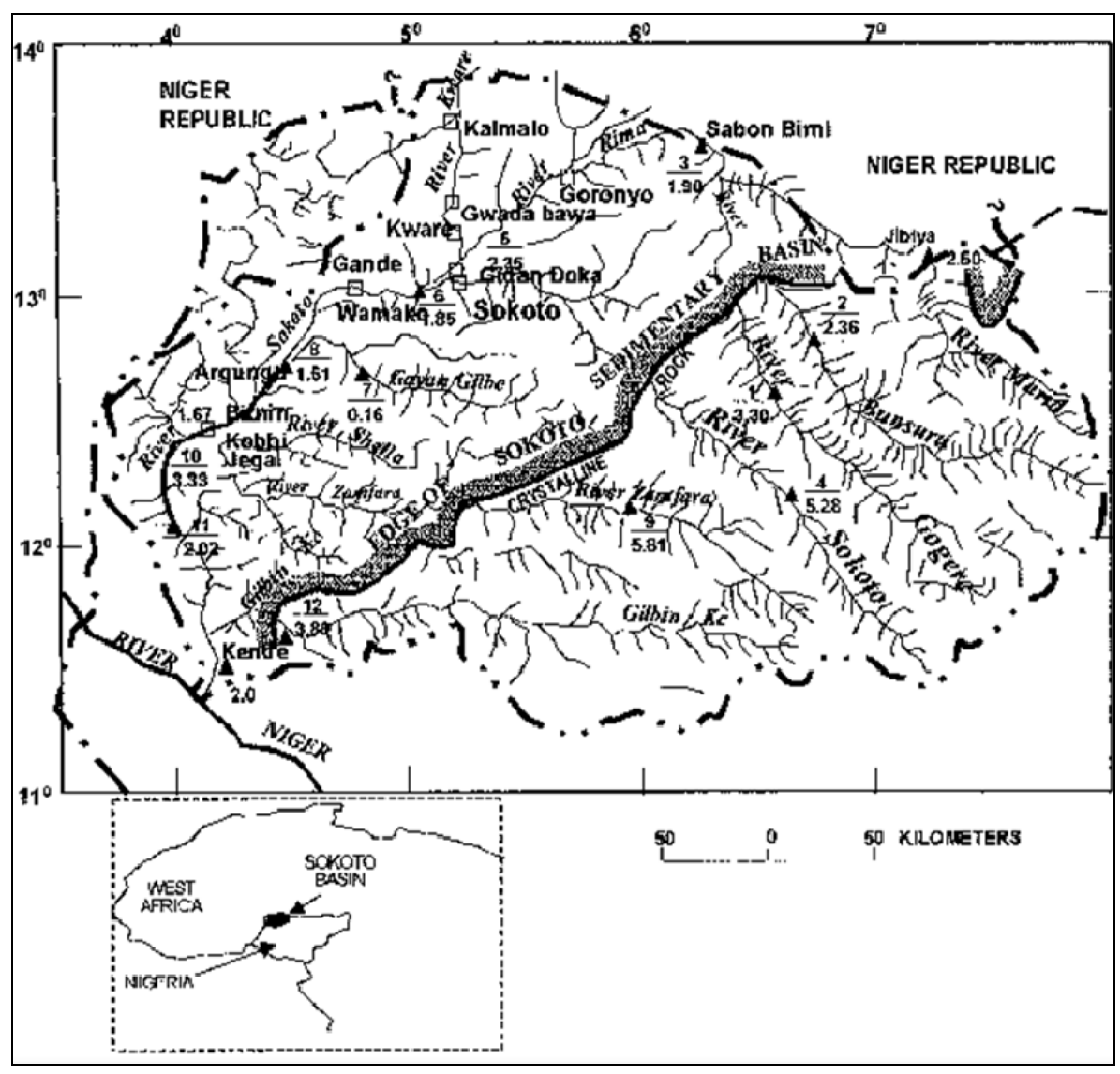

Figure 2. Hydrographic map of the Sokoto basin (Note the geologic divide: the shaded boundary of basement complex and sedimentary)

Source: Map Adapted from Adelana, Olasehinde and Vibraka (2006)

Three physiographic units are found in the basin: the uplands or high plains of the east and southeast, the Sokoto plains of the north and the center and lastly the marine lowland of the Niger and lower Rima valley. The high plains is made up of dissected plateau of complex crystalline rock characterized by ranges of hills and massif, smooth, dome shaped hills (inselberg). This has an average height of $700 \mathrm{~m}$. The Sokoto plains form monotonous lowland derived from softer sedimentary rocks with an average height of 300 metres. The flood plains are wide sometimes about $8 \mathrm{~km}$ apart; they are complex in nature.

Two major geological formations are discernable. These are basement complex rocks comprising old volcanic and metamorphic rocks which are mainly granite and metasediments. The granite comprises of undifferentiated granites, gneisses, migmitites and other related rock types which are resistant to erosion. In the northwestern part of the state, the basement complex is overlain by sedimentary rocks, in the lullmeden basin, extending from Sokoto, Niger to Mali. The deposits consist of Gundumi, Illo and the Rima and Sokoto groups otherwise known 
as Taloka, Dokomaje and Wurno formations. Gundumi formation is of lacustrine and fluviatile origin, consisting of clayey grits, clays and sandstone. Illo formation consists of pebbly grits, sandstones and clays, while Taloka-Wurno group consists of fine grained sandstones, mudstones, siltstones. The sedimentary materials are generally porous and rich in groundwater.

Drainage is somehow radial in nature. Main tributaries rise from the south eastern part of the state and in neighboring Kaduna state. The major rivers are: Gagere, Bunsare and Maradi. They flow northward and later unite to form Rima River. On the basement complex, drainage pattern is dendritic. Drainage density is high on metamorphic rocks. On the basement complex, gradients are steeper; on leaving the Precambrian they developed wide flood plains.

On the upper part where deposition is greatest rivers become wide and shallow. The width of the flood plain bears no relation to the present flow. Their size can be as a result of climatic changes that have taken place in the quaternary era, when the Pleistocene climate was wetter. Only rivers Niger and Rima are perennial. There is little groundwater recharge in the basement complex as rivers on them cease to flow after rainy season.

Two hydrological regions are discernable; these are head water part of the catchment overlying the basement complex and the lower part of the catchment overlying the sedimentary rocks. The upper part forms the headwaters of river Rima, it is faster, rapid, it has higher drainage density, steeper gradients, lower infiltration and higher runoff coefficient. It also has a faster flood wave compared to the other half where the sedimentary rocks have caused higher infiltration and lower runoff coefficient.

Table 1. Basin parameters

\begin{tabular}{|c|c|c|}
\hline & Basin variables & Methods \\
\hline 1 & Relief ratio & Total relief/Total stream length (Schumn,1956) \\
\hline 2 & Bifurcation Ratio & Horton, 1945 \\
\hline 2 & Drainage density & Total lengths of streams/basin area \\
\hline 3 & Stream frequency & No of stream segments /basin area \\
\hline 4 & Drainage intensity & Drainage density + stream frequency \\
\hline 5 & Form factor & Basin area/ (basin length) $)^{2}($ Black, 1991) \\
\hline 6 & Elongation ratio & Diameter of a circle having the same area as basin/ basin length (Schumn,1956) \\
\hline 7 & Circularity ratio & $\begin{array}{l}\text { Basin area/area of a circle having circumference equal to the basin perimeter. } \\
\text { Miller,1953) }\end{array}$ \\
\hline 8 & Basin relief & Altitude difference between highest and lowest point \\
\hline 9 & Relative relief & Basin relief/ basin perimeter ( Schumn,1956) \\
\hline 10 & Compaction ratio & $\begin{array}{l}\text { Basin perimeter/perimeter of the circle having the same as basin area. } \\
\text { (strahler,1964) }\end{array}$ \\
\hline 11 & Texture topography & No of tributaries/basin perimeter \\
\hline 12 & Relief gradient & $\begin{array}{l}\text { Mean elevation-min elevation/maximum elevation -min elevation (Pike and } \\
\text { Wilson) }\end{array}$ \\
\hline 13 & Width-length ratio & Maximum width of the basin/ maximum length of the basin (Al-Saud,2009) \\
\hline 14 & Ruggedness no & Basin relief + drainage density (Melton, 1957, Strahler,1958) \\
\hline 15 & Maximum relief & Highest elevation-lowest elevation \\
\hline 16 & $\begin{array}{l}\text { Length of overland } \\
\text { flow }\end{array}$ & $1 / 2$ of the reciprocal of drainage density (Horton,1945) \\
\hline 17 & Wandering ratio & Mainstream length/ basin length \\
\hline 18 & Fitness ratio & Stream length/ length of basin perimeter (Melton, 1957) \\
\hline 19 & Unit shape factor & Basin length/ (basin area) ${ }^{1 / 2}$ (Surken,1967) \\
\hline 20 & Basin shape factor & $\begin{array}{l}\text { Main stream length/ diameter of a circle having the area as the basin(Wu,et } \\
\text { al,1964) }\end{array}$ \\
\hline 21 & $\begin{array}{l}\text { Constant of stream } \\
\text { maintenance }\end{array}$ & Inverse of drainage density (Schumn,1956) \\
\hline 22 & $\begin{array}{l}\text { Volume } \\
\text { precipitated water }\end{array}$ & $\begin{array}{l}\mathrm{P}=\mathrm{Ac}(\mathrm{M}) * \operatorname{Pr}(\mathrm{M}) \text { where } \mathrm{P}=\text { precipitated water, } \mathrm{Ac}=\text { catchment size, } \mathrm{Pr}=\text { average } \\
\text { precipitation (Al-Saud,1958) }\end{array}$ \\
\hline
\end{tabular}

Note: All other parameters where computed by ILWIS 


\section{Materials and Method}

The data used in this study is the Shuttle Radar Topographic Mission (SRTM) image, downloaded from the NASA website using http://dds.cr.usgs.gov/srtm/. It is a Digital Elevation Model (DEM) of 90-meter resolution. Archived as 1-by-1 degree tiles and stored as .hgt file format, the data were imported into the Integrated Land and Water Information System (ILWIS) and ArcGIS environments and subsequently georeferenced to Longitude and Latitude coordinate system. As the Sokoto-Rima Basin is located within longitudes 50 and $70 \mathrm{E}$ and latitudes 120 and $140 \mathrm{~N}$, tiles forming this coverage were glued and the exact basin area sub-mapped (Figures 3 and 4).

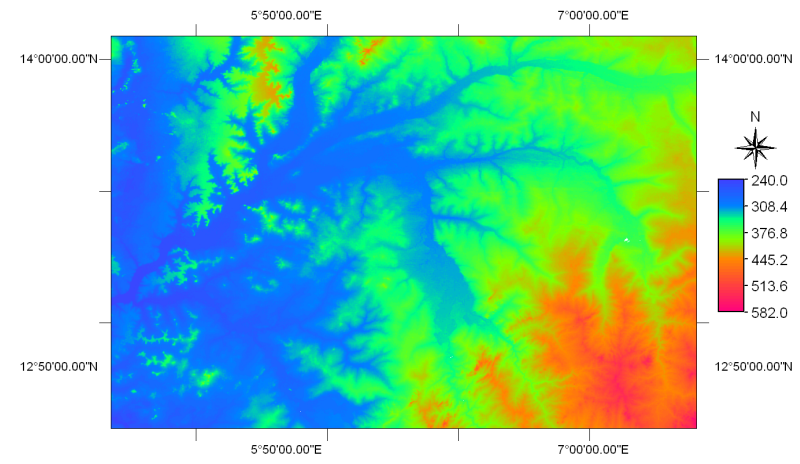

Figure 3. SRTM of the Sokoto-Rima Basin

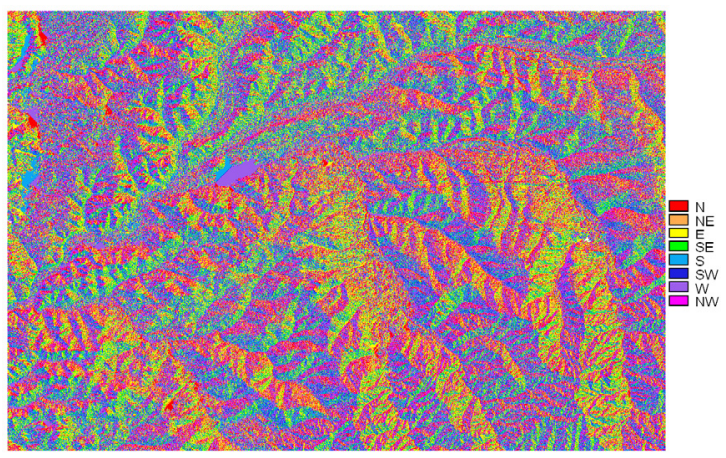

Figure 4. Flow Direction Map

For a meaningful morphometric analysis, sinks were removed from the SRTM, and the flow direction map was generated as an input for drainage extraction, river ordering and basin catchments (Figure 5). Drainage network overlay was carried out on the generated hill-shade map (Figure 6) and on a portion of SPOT image (Figures 7 and 8) covering Sokoto metropolis for analytical purpose.

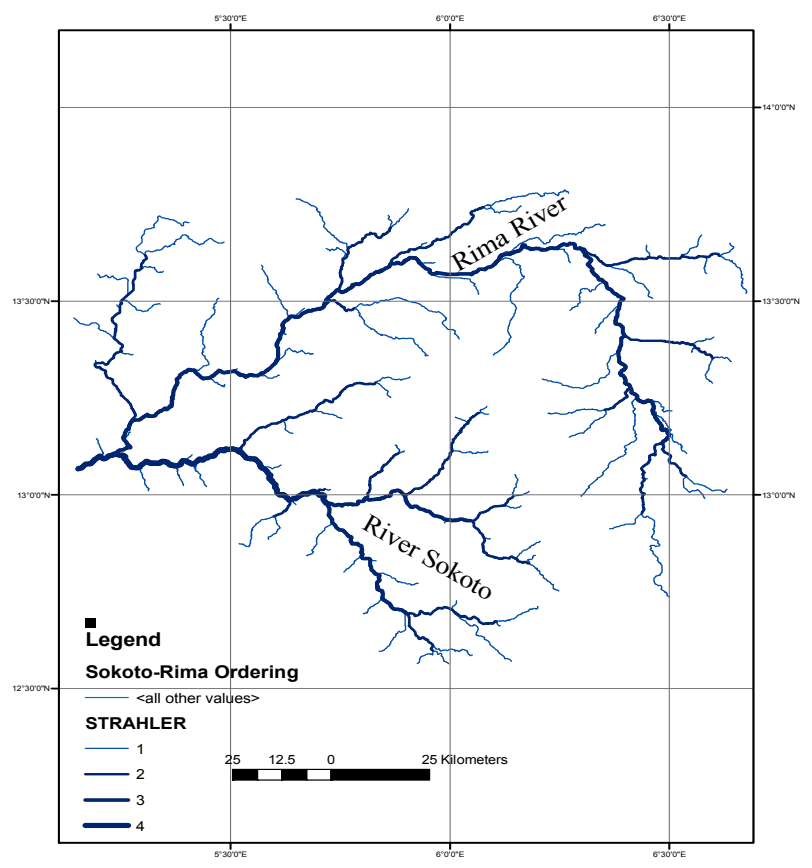

Figure 5. Drainage Order of Sokoto-Rima System

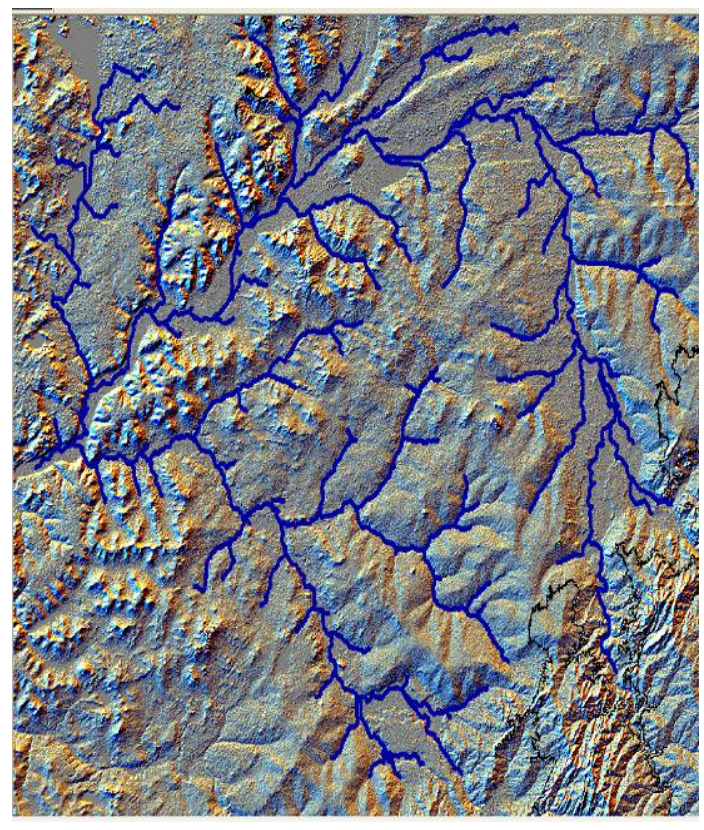

Figure 6. Hillshade Overlaid with Drainage Network 


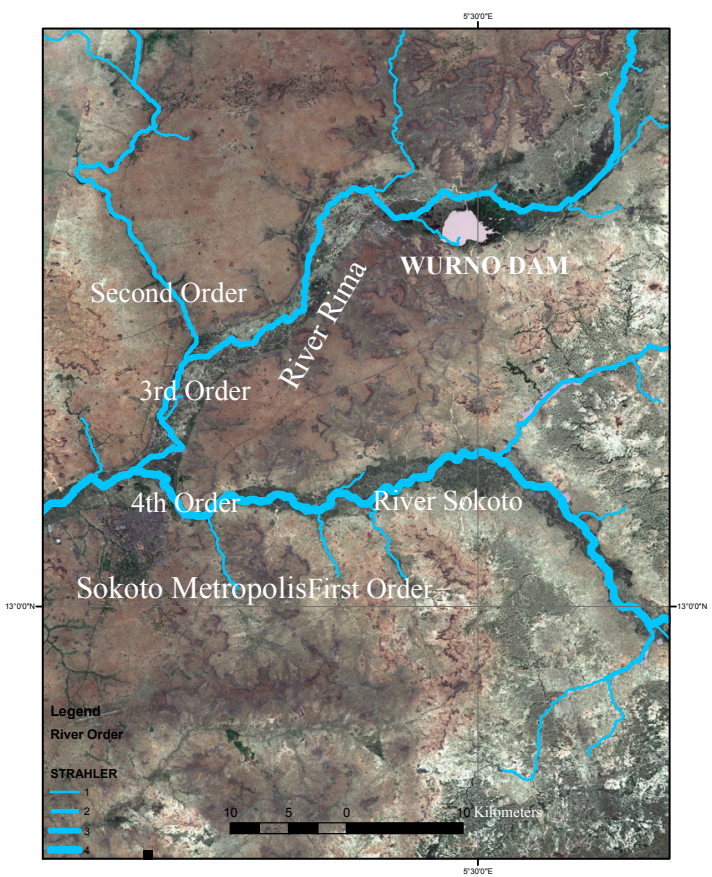

Figure 7. SPOT image showing Sokoto Metropolis

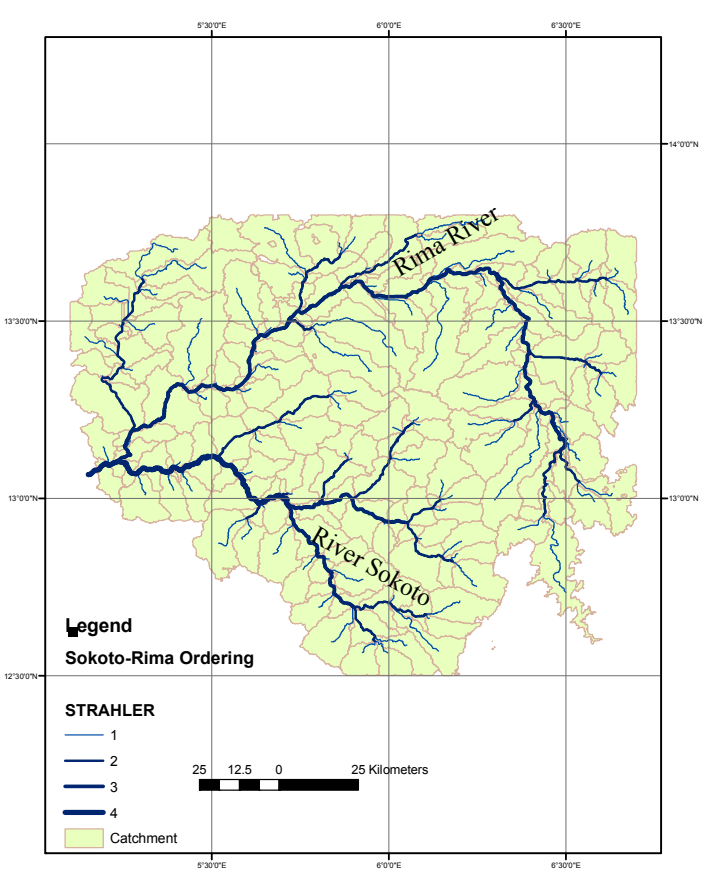

Figure 8. Sokoto-Rima Catchments

\section{Basin Characteristics}

According to the results presented in Table 2, relief ratio in the Sokoto basin is 0.0002 . This suggests that the Sokoto basin is a low-lying. It also depicts an existence of an extensive flood plain. This type of terrain is suggestive of high sediment delivery ratio. Further, Sokoto basin will be prone to frequent flooding. This agrees with the submission that a large part of the Sokoto basin is oceanic in origin. In addition, this relatively low relief ratio is an indication of a low stream gradient, minimum slope and drainage density $\left(0.1 \mathrm{~km} / \mathrm{km}^{2}\right)$. However, the low relief ratio is typical of a dry sub humid or Sahel region of low rainfall, and a sedimentary geology with low drainage density and a rolling topography which is typical of the study area. It has been discovered that the lower the drainage density, the lower the stream velocity, and the higher the rate of channel deposition and sedimentation. The low drainage density implies widely spaced steams due to the pressure of less resistance rocks, and high rate of siltation.

Stream frequency measures the amount of rivers per unit area. The Sokoto basin has a stream frequency of 0.004 . It shows that the basin is poorly drained, and this is indicative of the numbers of stream per unit area. The value of stream frequency implies that there are few streams per unit area in the Sokoto basin. It also suggests that there are few drainage outlets or channels on the basin. The river Rima-Sokoto is the dominant river in the region. This can be explained in terms of the sedimentary geology of the study area. This implies that only limited output is available for storm runoff, a condition which could easily trigger-up a flood disaster. The capacity of the few water outlets may be exceeded almost immediately during and after a storm and such will lead to flood. Drainage Intensity is $0.104 \mathrm{~km} / \mathrm{km} 2$; it measures the potential of the basin to adequately evacuate generated storm flow as fast as possible. This value again is weak for an efficient water evacuation process. The low drainage intensity suggest a high flood wave; a condition which has effect on hydrograph time relations such as time of concentration, time lag, time to peak and hydrograph peak.

The shape of the Upper Sokoto basin would also influence the shape of the hydrograph. The shape indices considered in this study indicate that Sokoto Basin is a circular basin where travel time and time of concentration are short. Mustapha and Yusuf (1999) observed that elongation ratio should range from 0.4-1.0; while Chow (1964) equally reported basin elongation ratio to be in the range of 0.40 and 0.50 . Circularity ratio for Sokoto basin is 0.68 , suggesting the closeness of the basin to a circle. This therefore means shorter times of travel, concentration, lag time, and shorter flood peak. Form factor is 0.054 , which further support the circularity of the basin. 
Table 2. Computed values of selected basin variables in Upper Sokoto basin

\begin{tabular}{|c|c|c|}
\hline 1 & Relief Ratio & -0.0002 \\
\hline 2 & Drainage Density & $\left.0.1 \mathrm{~km} / \mathrm{km}^{2}\right)$ \\
\hline 3 & Stream Frequency & -0.004 \\
\hline 4 & Drainage Intensity & -0.104 \\
\hline 5 & Form Facto & 0.054 \\
\hline 6 & Elongation Ratio & 0.30 \\
\hline 7 & Circulatory Ration & 0.68 \\
\hline \multirow{3}{*}{8} & Bifurcation Ratio & -5.2 \\
\hline & First Order/Second Order & 5.3 \\
\hline & Third Order/Fourth Order & 3.0 \\
\hline \multirow{5}{*}{9} & Stream Order & \\
\hline & $\mathrm{I}^{\mathrm{St}}$ Order & 83 \\
\hline & Second Order & 16 \\
\hline & Third Order & 3 \\
\hline & Fourth Order & 1 \\
\hline 10 & Total Stream Length & $2,320 \mathrm{~km}$ \\
\hline 11 & Basin Relief & $347 \mathrm{ft}$ \\
\hline 12 & Relative Relief & 0.51 \\
\hline 13 & Sinuosity Index & $\mathrm{Min}=1 ; \mathrm{Av}=1.2 ; \mathrm{Max}=1.81$ \\
\hline 14 & Compaction Ratio & 0.57 \\
\hline 15 & Texture Topography & 0.15 \\
\hline 16 & Relief Gradient & 0.25 \\
\hline 17 & Width-Length Ratio & 0.83 \\
\hline 18 & Ruggedness No & 347.1 \\
\hline 19 & Basin Area & $25,206.6 \mathrm{~km}^{2}$ \\
\hline 20 & Length Of Overland Flow & 5 \\
\hline 21 & Basin Length & $173.04 \mathrm{~km}$. \\
\hline 22 & Wandering Ratio & 1.70 \\
\hline 23 & Fitness Ratio & 2.70 \\
\hline 24 & Unit Shape Factor & 0.007 \\
\hline 25 & Basin Shape Factor & 1.64 \\
\hline 26 & Constant Of Stream Maintenance & 10 \\
\hline 27 & Total river length & $1,822 \mathrm{~km}$ \\
\hline 28 & Minimum Sinuosity & 1 \\
\hline 29 & Average Sinuosity & 1.244 \\
\hline 30 & Maximum Sinuosity & 1.806 \\
\hline 31 & Perimeter of Basin & $684.9 \mathrm{~km}$ \\
\hline 32 & Area of the Basin & $25,206.6 \mathrm{~km}^{2}$ \\
\hline 33 & Shortest Stream Length in the basin & $0.9004 \mathrm{~km}$ \\
\hline 34 & Longest Stream Length in the basin & $41.7107 \mathrm{~km}$ \\
\hline 35 & Total Stream Length in the Basin & $2,320 \mathrm{~km}$ \\
\hline 36 & Minimum Slope along Drainage & $0^{\circ}$ \\
\hline 37 & Maximum Slope along Drainage & $44.4^{\circ}$ \\
\hline 38 & Minimum Stream Order & 1 \\
\hline 39 & Maximum Stream Order & 4 \\
\hline 40 & Maximum Elevation & 582 \\
\hline 41 & Minimum Elevation & 235 \\
\hline 42 & Volume Of Precipitated Water & $14,511,439,620 \mathrm{~m}^{3} /$ year \\
\hline
\end{tabular}

Bifurcation ratio of the different basin orders in the study area ranges from 3.0 to 5.3. This indicates a relatively low value of bifurcation ratio, particularly, bifurcation ratio of order 3 to 4 . This means flood peak is easily achieved. This suggests that the Sokoto basin is liable to flooding. The values ranges from 3.0-5.3, it is suggestive of the relatively low impact of man on the Sokoto basin, and the fact that the basin is underlain by a homogenous rock (Kule \& Gapta, 2001). 
Relative relief in the Sokoto basin is 0.5 ; this ratio shows the average slope in the basin. The value is relatively low, and it indicates low channel velocity, therefore rate of channel erosion will be low and there will be high rate of deposition. Sinuosity is of prime importance to aquatic lives and rate of channel deposition. The average sinuosity of river Sokoto at Sokoto is 1.24; suggesting that Sokoto River is meandering (Brice, 1964; Stuart, 1966; Eziashi, 1999,). This is expected in alluvial channels such as river Sokoto. Sinuosity will lead to higher rates of deposition, and less of transformation and unnecessarily higher flood risk.

Compaction ratio for Sokoto is 0.57 , this coefficient indicates the nature of the surface, and it shows that the basin is not an elongated one but rather compacted. It also suggests fast flood peak. The value of texture topography is 0.5 , showing low drainage dissection. The low value is expected in view of the level of permeability in the basin due to the sedimentary geology. The basin comprises of Illo, Wurno, etc which are known for their permeability. The texture topography recorded for Sokoto basin is a soft category (Smith, 1950, At-Saud (2009). Relief gradient an indication of land mass maturity is 0.25 it expresses the ratio of upland to lowland elevation within the catchments area. The value is an indication that this basin is going into stage of maturity (Pike \& Wilson, 1971; Al-Saud, 2009). Width- length ratio is 0.83 . The

Width length ratio is an indication of the time it takes runoff to effectively reach the major water courses. According to Davies (1982) river Sokoto channels is quite wide and sometimes may be about $8 \mathrm{~km}$ sometimes. The higher the width-length ratio, the longer will be the runoff duration. The value obtained suggests adequate time lag for infiltration process hence, flood will be experienced, and whenever it is experienced it may be very disastrous. Ruggedness number is a measure of the level dissection along a basin. The value expresses the rolling nature of the basin. The value recorded is 2.3 this shows that the basin is not rugged. The length of overland flow is the expression of the concentration time, particularly of overland flow which can translate to flood. The value recorded in this study is 0.05 . This somehow suggests a low proportion. However, this value is expected in view of the sedimentary nature of the basin whereby, surface runoff is a small portion of the total runoff hydrograph. Wandering ratio is quite high (1.70) suggesting that River Sokoto is highly sinuous. The fitness ratio of river Sokoto is 2.70 suggesting that, the stream course agrees with the length of mainstream almost perfectly. The unit shape factor is 0.08 indicating that the basin is far from linear in nature however, the basin shape further indicate the flow of water is regular.

\section{Implication for Flood Management}

The results presented in Table 2, clearly point to the fact that the Sokoto Basin is an alluvial basin that is located in a relatively low lying area where high level of deposition is experienced. The results indicate that the river channel is liable to flooding, especially in view of its sinuous nature coupled with its spherical shape. The result also point to the basin as a compact basin; where flood can early be generated. However, a look at these characteristics coupled with the relatively high volume of precipitated water of $14,511,439,620 \mathrm{~m}^{3} / \mathrm{year}$ is an indication that the basin has high flood potential.

Although it has wide flood plain, high groundwater recharge and high groundwater component, longer time of concentration, time to peak, etc. Flood on the Sokoto basin is likely to be to be generated by multiple event rainfall, high antecedent precipitation, or through hydraulic accidents. In cases of flood events, such events would be disastrous in view of the wideness and flatness of the channel and the relatively flat terrain which will allow extensive spreading of flood water; a condition which will have damaging toll on lives and properties. For example, the 2010 September flood led to the death of 40 people, washing away of 7,196 houses and 11,100 farmlands and rendered 35,000 people homeless (Sokoto Environmental Relief Agency, Sokoto; Punch 18th September, 2010).

In addition, dam or hydraulic structures constructed along river Sokoto will face problems of siltation and sedimentation. This is because of the values of river competence, sinuosity, compactness, wandering ratio, constant of stream maintenance, fitness ratio that were computed for Sokoto basin. All these indices point to Sokoto River as relatively sluggish therefore the designs of water structures such as dams, weirs and culverts and bridges, must have provision for getting rid of sediments. This condition is worsened by the unsustainable land use management techniques such as grazing, overgrazing, traditional agriculture that dominate the bank of river Sokoto. Indeed, the basin is $100 \%$ cultivated. For purposes of agricultural production, there is need to construct levees along the channel, this will help claim back vast expanse of agricultural land which would had hitherto been flooded due to indiscriminate spreading of water from the channels. Further, there is a need to properly develop an efficient agricultural management framework for fadama agriculture. 


\section{References}

Al-Saud. (2009). Watershed characteristics of Wadi Hurnah, western Arabian Peninsula. Journal of Water Resource and Protection, 1, 316-324. http://dx.doi.org/10.4236/jwarp.2009.15038

Berger, K. P., \& Entekhabi, D. (2001). Basin hydrologic response relations to distributed physiographic descriptors and climate. Journal of Hydrology, 247, 169-182. http://dx.doi.org/10.1016/S0022-1694(01)00383-3

Brice, J. C. (1964). Channel pattern and terraces of the Loup Rivers, Nebraska. U.S. Geological Survey. Prof Paper 422D, $41 \mathrm{pp}$.

Chow, V. T. (1964). Runoff in Hand Book of Applied Hydrology.

Eze, B. E., \& Effiong. (2010). Morphometric parameters of the Calabar river basin: implications for hydrologic processes. Journal of Geography and Geology, 2(1), 18-26.

Eziashi, A. C. (1999). An appraisal of the existing descriptive measures of river channel patterns. Journal of Environmental Sciences, 3(2), 253-257.

Grsgory, K. J. (1976). Drainage networks and climate. Chapter 10 in Geomorphology and Climate (E, Derbyshire ed.). London: John Wiley.

Kale, V. S., \& Gupta, A. (2001). Introduction to Geomorphology. New Delhi: Academic Publisher India. Chapter 3.

Leopold, L. B., \& Wolman, M. G. (1957). River channel patterns braided, meandering and straight. U.S. Geological Survey. Prof. Paper 282B, 39-85.

Melton, M. A. (1957). An analysis of the relations among the elements of climate, surface properties and geomorphology. Technical Report II. New York Department of Geology, Columbia University.

Morgan, R. P. C. (1976). The role of climate in the denudation system: A case study from west Malaysia. Chapter II in Geomorphology and Climate (Derbyshire, E ed.). London: John Wiley and sons.

Pike, R., \& Wilson, S. (1971). Elevation-relief ratio, hypsometric integral and geomorphic area- altitude analysis. GSA Bull, 82, 1079-1084. http://dx.doi.org/10.1130/0016-7606(1971)82[1079:ERHIAG]2.0.CO;2

Pinchmel, P. H. (1957). Densities de drainage et densities et densities des Valles. Tijol ker Ned Ard-Kun. Genoots, 373-376.

Rodriguez-Iturbe, I., \& Escobar, L. A. (1982). The dependence of drainage density on climate and $\begin{array}{lllll}\text { geomorphology. Hydrological } & \text { Sciences }\end{array}$ http://dx.doi.org/10.1080/02626668209491095

Ruhe, R. V. (1952). Topographic discontinuities of des Moines lobe. Journal of Science, 250, 46-56.

Shaymaker, H. O. (1968). Morphometric analysis of the west wales region - A practical class Project a Morphometrical Analysis of Maps, 5-9. British Geomorphological Resource Group Occasional Paper.4.

Smith, K. (1950). Standard for grinding texture of erosional topography. America Journal of Science, 248, 655-668. http://dx.doi.org/10.2475/ajs.248.9.655

Sreenivasulu, V., \& Bhaskar, P. U. (2010). Estimation of catchment characteristics using remote sensing and GIS techniques. International Journal of Engineering Sciences and Technology, 2(12), 7763-7770.

Strahler, A. N. (1964). Quantitative geomorphology of drainage basin and channel networks chapter 4 in Handbook of Applied Hydrology (e V. T. Chow (ed)). New York: MC Graw Hill.

Woodyer, K. D., \& Brookfield, M. (1966). The land system and its stream net CSIRO Div of Land Resources Tech. Mem. 66/5.

Yildz, O. (2004). An investigation of the sheet of drainage density on hydrologic response. Turkish Journal of Engineering and Environmental Sciences, 28, 85-94. 